\title{
Biomass burning contribution to black carbon in the Western United States Mountain Ranges
}

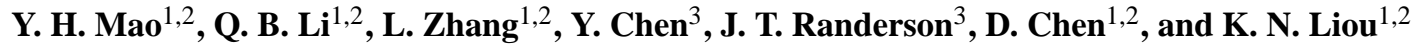 \\ ${ }^{1}$ Department of Atmospheric and Oceanic Sciences, University of California, Los Angeles, CA 90095, USA \\ ${ }^{2}$ Joint Institute for Regional Earth System Science and Engineering, University of California, Los Angeles, CA 90095, USA \\ ${ }^{3}$ Department of Earth System Science, University of California, Irvine, CA 92697, USA
}

Received: 11 April 2011 - Published in Atmos. Chem. Phys. Discuss.: 3 May 2011

Revised: 21 October 2011 - Accepted: 24 October 2011 - Published: 11 November 2011

\begin{abstract}
Forest fires are an important source to carbonaceous aerosols in the Western United States (WUS). We quantify the relative contribution of biomass burning to black carbon (BC) in the WUS mountain ranges by analyzing surface BC observations for 2006 from the Interagency Monitoring of PROtected Visual Environment (IMPROVE) network using the GEOS-Chem global chemical transport model. Observed surface $\mathrm{BC}$ concentrations show broad maxima during late June to early November. Enhanced potassium concentrations and potassium/sulfur ratios observed during the high$\mathrm{BC}$ events indicate a dominant biomass burning influence during the peak fire season. Model surface $\mathrm{BC}$ reproduces the observed day-to day and synoptic variabilities in regions downwind of but near urban centers. Major discrepancies are found at elevated mountainous sites during the July-October fire season when simulated BC concentrations are biased low by a factor of two. We attribute these low biases largely to the underestimated (by more than a factor of two) and temporally misplaced biomass burning emissions of $\mathrm{BC}$ in the model. Additionally, we find that the biomass burning contribution to surface BC concentrations in the USA likely was underestimated in a previous study using GEOS-Chem (Park et al., 2003), because of the unusually low planetary boundary layer (PBL) heights in the GEOS-3 meteorological reanalysis data used to drive the model. PBL heights from GEOS-4 and GEOS-5 reanalysis data are comparable to those from the North American Regional Reanalysis (NARR). Model simulations show slightly improved agreements with the observations when driven by GEOS-5 reanalysis data, but model results are still biased low. The use of biomass burning emis-
\end{abstract}

Correspondence to: Q. B. $\mathrm{Li}$

(qli@atmos.ucla.edu) sions with diurnal cycle, synoptic variability, and plume injection has relatively small impact on the simulated surface $\mathrm{BC}$ concentrations in the WUS.

\section{Introduction}

Black Carbon (BC) is a product of incomplete combustion of carbonaceous fuels (Bond et al., 2004). It is strongly absorptive of solar radiation and has considerable impacts on global climate (Flanner et al., 2007, 2009; IPCC, 2007; Hansen and Nazarenko, 2004; Jacobson, 2001, 2004). BC deposited on snow and ice can significantly decrease the surface albedo (Warren and Wiscombe, 1980). The reduced snow albedo enhances surface snowmelt (Flanner et al., 2007; Zwally et al., 2002) and can potentially change the regional hydrological cycle over mountain ranges (e.g. Qian et al., 2009). Globally the direct radiative forcing due to fossil fuel $\mathrm{BC}$ was estimated to be $+0.2 \pm 0.15 \mathrm{Wm}^{-2}$ and the radiative forcing of snow/ice albedo effect due to $\mathrm{BC}$ was $+0.1 \pm 0.1 \mathrm{Wm}^{-2}$ (IPCC, 2007). Freshly emitted BC is mostly hydrophobic and becomes hydrophilic by oxidation or by coating with sulfate and organics in about 1-2 days (Park et al., 2003 and references therein). $\mathrm{BC}$ is removed from the atmosphere within days to weeks primarily by wet deposition (Jacobson, 2004). Because of its shorter lifetime relative to longlived greenhouse gases such as carbon dioxide, BC shows a much stronger regional warming effect and its reduction may provide an efficient short-term solution to combat global warming (Ramana et al., 2010; Ramanathan and Carmichael, 2008; Bond and Sun, 2005; Hansen et al., 2005).

Globally, the annual emissions of $\mathrm{BC}$ are mainly from three sources: about $40 \%$ from fossil fuels, $40 \%$ from

Published by Copernicus Publications on behalf of the European Geosciences Union. 
biomass burning and $20 \%$ from biofuels (Bond et al., 2004; Cooke et al., 1999). The uncertainty in current BC emission estimates ranges from at least $\pm 50 \%$ on global scales to a factor of 2-5 on regional scales (Ramanathan and Carmichael, 2008; Streets et al., 2001, 2003). The most recent generation of fire emission inventories is based on a combined approach using burned area and active fire counts from satellites, accompanied by biogeochemical modeling of available fuel load (van der Werf et al., 2006, 2010; Langmann et al., 2009). Biomass burning emissions are typically calculated as the product of burned area, fuel load, combustion completeness, and emission factors (van der Werf et al., 2006, 2010; Langmann et al., 2009; Seiler and Crutzen, 1980). Even though fire emission inventories have improved considerably in recent years, large uncertainties remain in the temporal and spatial variations of fire emissions, particularly from burned area and fuel load (Langmann et al., 2009). Small fires are likely a major source of uncertainty in the estimates of biomass burning emissions of BC. For instance, small fires can lead to high relative errors of $50-100 \%$ in the estimates of burned area (Giglio et al., 2006, 2010). Additionally, the lack of detection for or under-detection of agricultural burnings in satellite active fire detection algorithms may be another large uncertainty (van der Werf et al., 2010; Korontzi et al., 2006).

Recent studies have shown that the transport and subsequent deposition of BC in the Western United States (WUS) mountain ranges may significantly impact the region's climate and hydrological cycle. In the WUS, mountain snowmelt accounts for more than $70 \%$ of the annual stream flows (Qian et al., 2009). A modeling study by Qian et al. (2009) using the WRF-Chem model showed that the deposition of $\mathrm{BC}$ on snow over the WUS mountain ranges led to increased rain but less snow accumulation in winter. This change in the precipitation pattern resulted in reduced and earlier snowmelt in spring. Consequently runoff from snowmelt between April and June decreased, adversely affecting the supply of fresh water in the Western states.

It is thus imperative to better understand the sources, transport, and deposition of $\mathrm{BC}$ in the WUS mountain ranges. BC in this region is mainly from North American anthropogenic emissions (Park et al., 2003), transpacific transport of Asian emissions especially during spring (Chin et al., 2007; Hadley et al., 2007; Park et al., 2003), and North American biomass burning emissions during the summer and fall fire season (Spracklen et al., 2009; Park et al., 2003). However, the relative contributions from these sources particularly biomass burning to BC in the WUS are still uncertain. Wildfires are an important source to carbonaceous aerosols in the WUS (Zeng et al., 2011; Spracklen et al., 2007, 2009; Jaffe et al., 2008; Park et al., 2007). The increase of fire frequency and prolonged fire seasons observed in the WUS in recent decades have been linked to increased spring and summer temperatures and an earlier spring snowmelt (Westerling et al., 2006). The modeling study by Spracklen et al. (2009) showed that the annual mean area burned in the WUS could increase by $54 \%$ by the 2050 s relative to the present under future warming. It is conceivable that fires will be an even larger contributor to BC in the WUS in the 21st century, especially considering that North American anthropogenic emissions are trending down due to aggressive emission reduction regulations (Ramanathan and Carmichael, 2008; Bond et al., 2007; Novakov et al., 2003). For the transpacific transport of Asian emissions, it is likely that Asian BC emissions will continue to increase in the coming decades due to the rapid economic developments in that region (Zhang et al., 2009; Bond et al., 2007; IPCC, 2007; Streets et al., 2003; Novakov et al., 2003). The large uncertainties in $\mathrm{BC}$ emissions again warrant better understanding of the sources of BC in the WUS mountain ranges.

The goal of the present study is to improve our understanding of the sources, transport, and deposition of $\mathrm{BC}$ in the WUS mountain ranges. Our approach is to apply a global three-dimensional (3-D) chemical transport model (CTM) to analyze surface $\mathrm{BC}$ observations over the WUS. We intend to quantify the relative contributions from the different source types and source regions to surface $\mathrm{BC}$ concentrations in the WUS mountain ranges. Our focus is on the contributions from fires. Our analysis centers on 2006, a relatively strong fire year in terms of burned area in temperate North America (Giglio et al., 2010). We describe the observations and the GEOS-Chem global 3-D CTM in Sect. 2. We present our results and related discussions in Sect. 3. Conclusions are given in Sect. 4.

\section{Observations and model description}

\subsection{IMPROVE}

Long-term measurements of aerosols with chemical species including BC and elemental components of potassium (K) and sulfur (S) are available in the US from the Interagency Monitoring of Protected Visual Environment (IMPROVE) network since 1987 for the protection of visibility in Class I remote areas (Malm et al., 1994; data available at (http: //vista.cira.colostate.edu/improve/). Figure 1 shows 69 IMPROVE sites in the WU. These are remote sites at various elevations. IMPROVE measurements are made every three days for 2006 and twice a week for 1998. The reported values are $24 \mathrm{~h}$ averages. Thermal Optical Reflectance (TOR) combustion method was used for the BC measurements based on the preferential oxidation of organic carbon (OC) and BC at different temperatures (Chow et al., 2004). The uncertainties of the TOR method are difficult to quantify (Park et al., 2003; Chow et al., 1993).

Tanner et al. (2001) showed that the surface concentrations of $\mathrm{K}$ and the $\mathrm{K} / \mathrm{S}$ ratios significantly increased during wildfire episodes and were therefore good tracers of biomass burning. IMPROVE observations of $\mathrm{K}$ and $\mathrm{K} / \mathrm{S}$ are thus particularly 


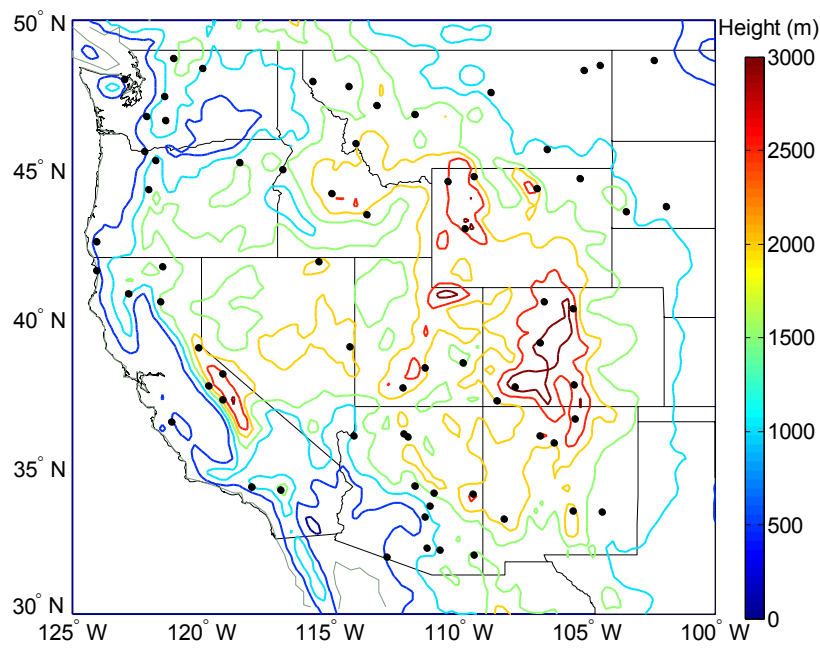

Fig. 1. IMPROVE sites (black dots; data available at http://vista. cira.colostate.edu/improve/) in the Western US. Also shown are terrain heights (color contours).

useful for identifying fire influence. Additionally, the IMPROVE data also provides surface soil dust concentrations that were calculated as the sum of the soil-derived elements ( $\mathrm{Al}, \mathrm{Si}, \mathrm{K}, \mathrm{Ca}, \mathrm{Ti}, \mathrm{Fe}$ ) and their normal oxides (Malm et al., 1994). The primary natural dust is wind-blown mineral dust while the main anthropogenic dust is road dust that contains carbon and metals (Wells et al., 2007; Kim et al., 2005). Previous studies have shown that surface dust concentrations in the WUS in spring were influenced by not only local sources (Hwang and Hopke, 2007; Wells et al., 2007) but also the transpacific transport of Asian dust (VanCuren and Cahill, 2002; Husar et al., 2001). Therefore, a combination of high dust concentrations and relative low $\mathrm{K}$ concentrations and $\mathrm{K} / \mathrm{S}$ ratios during relatively high-BC events in the WUS in spring indicates an anthropogenic rather than a fire influence on surface $\mathrm{BC}$ concentrations.

\subsection{GEOS-Chem description and simulations}

GEOS-Chem is a global 3-D CTM driven by assimilated meteorological observations from the NASA Goddard Earth Observing System (GEOS) (Bey et al., 2001). We use here GEOS-Chem version 8-01-04 (available at (http://acmg. seas.harvard.edu/geos/) driven by GEOS-3, GEOS-4, and GEOS-5 meteorological fields with $6 \mathrm{~h}$ temporal resolution ( $3 \mathrm{~h}$ for surface variables and mixing depths), $2^{\circ}$ latitude $\times 2.5^{\circ}$ longitude horizontal resolution, and 30 (GEOS-3, 4) or 47 (GEOS-5) vertical layers from the surface to $0.01 \mathrm{hPa}$. The lowest model levels are centered at approximately 10 , $50,100,200,350,600,850,1250$, and $1750 \mathrm{~m}$ above sea level in GEOS-3, 60, 250, 600, 1200, $2000 \mathrm{~m}$ in GEOS-4, and $60,200,300,450,600,700,850,1000,1150,1300$, $1450,1600,1800 \mathrm{~m}$ in GEOS-5.
Tracer advection is computed every 15 min with a fluxform semi-Lagrangian method (Lin and Rood, 1996). Tracer moist convection is computed using GEOS convective, entrainment, and detrainment mass fluxes as described by Allen et al. (1996a, b). The deep convection scheme of GEOS-4 is based on Zhang and McFarlane (1995), and the shallow convection treatment follows Hack (1994). GEOS-3 and GEOS5 convection is parameterized using the relaxed ArakawaSchubert scheme (Moorthi and Suarez, 1992; Arakawa and Schubert, 1974).

GEOS-Chem simulation of carbonaceous aerosols has been reported previously by Park et al. (2003). Eighty percent of $\mathrm{BC}$ and $50 \%$ of organic carbon (OC) emitted from primary sources are assumed to be hydrophobic and hydrophobic aerosols become hydrophilic with an e-folding time of 1.2 days (Park et al., 2003; Chin et al., 2002; Cooke et al., 1999). Global fossil fuel and biofuel emissions of BC are based upon Bond et al. (2004) with updated emissions for Asia (Zhang et al., 2009) and North America (Cooke et al., 1999).

Biomass burning emissions of $\mathrm{BC}$ are from version 2 of the Global Fire Emissions Database (GFEDv2) (Randerson et al., 2007; van der Werf et al., 2006). The GFED inventory was derived using satellite observations including active fire counts and burned areas in conjunction with a biogeochemical model. Burned areas were derived using active fire counts and 500-m burned area datasets from the Moderate Resolution Imaging Spectroradiometer (MODIS) as described by Giglio et al. (2006). Total carbon emissions were calculated as the product of burned area, fuel load and combustion completeness. Fuel load depends on vegetation type, climate, soil type and time since last fire, while combustion completeness, describing the fraction of the available fuel combusted during a fire, depends on the type of fire, the type of fuel (e.g. stems, leaves and litter) and its moisture content (Langmann et al., 2009). For GFED, the Carnegie-Ames-Stanford-Approach (CASA) biogeochemical model was used to estimate combustion completeness as well as fuel load and the associated spatial variability (van der Werf et al., 2006, and references therein). $\mathrm{BC}$ emissions were then derived from the total carbon emissions based on BC emission factors. Figure 2 shows the monthly mean total carbon emissions in the WUS (100$125^{\circ} \mathrm{W}, 30-50^{\circ} \mathrm{N}$ ) for 2006 . The fire season started in April and lasted through November. The GFEDv2 inventory has a multitude of temporal resolutions from monthly, 8-day, to 3-hourly with diurnal cycles (for 2004 only), as reported previously by Chen et al. (2009). Forest fires typically last from several days to weeks as seen in MODIS active fires (Giglio et al., 2006). The 8-day emissions were re-sampling of the standard GFEDv2 monthly emissions to an 8-day time step according to MODIS 8-day active fire counts (Chen et al., 2009).

Simulation of aerosol wet and dry deposition follows Liu et al. (2001). Wet deposition includes contributions from scavenging in convective updrafts, rainout from convective 


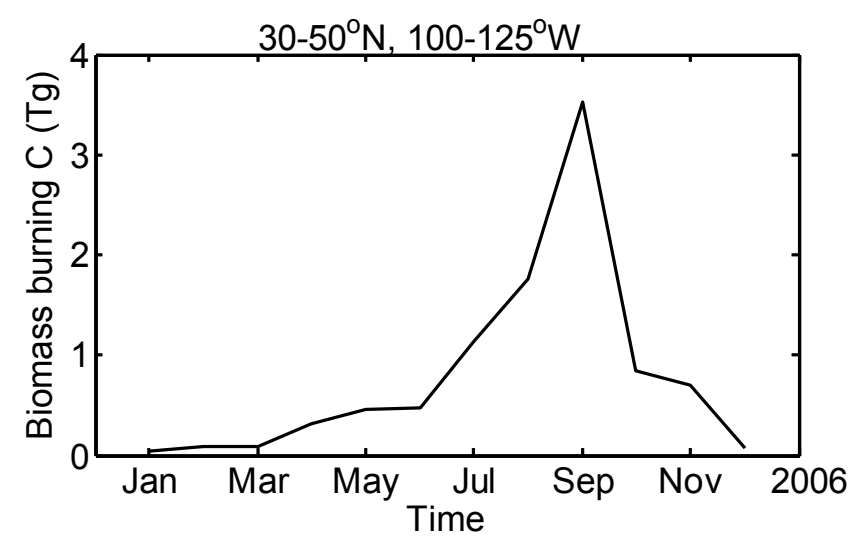

Fig. 2. GFEDv2 monthly total carbon emissions from fires in the Western US $\left(100-125^{\circ} \mathrm{W}, 30-50^{\circ} \mathrm{N}\right)$ for 2006 .

anvils, and rainout and washout from large-scale precipitation. Dry deposition of aerosols uses a resistance-in-series model (Walcek et al., 1986) dependent on local surface type and meteorological conditions.

For the present study, we conducted GEOS-Chem "offline" carbonaceous aerosols simulations (Park et al., 2003) for 2006, driven by GEOS-4 and GEOS-5 meteorological fields. We use GFEDv2 8-day emissions unless stated otherwise. In addition, we conducted two model simulations for 1998 driven by GEOS-3 and by GEOS-4 meteorological fields. In the last two simulations, emissions including those from biomass burning were exactly the same as those used by Park et al. (2003). Detailed discussions and justifications for these model simulations are provided in the following sections where appropriate.

Model results are sampled at the corresponding locations of the IMPROVE sites. IMPROVE observations are $24 \mathrm{~h}$ averages sampled every three days and we sample the model accordingly. We would like to point out that comparing localized observations such as the IMPROVE data with model results that are representative of a much larger area is inherently problematic. The comparison is further complicated by the fact that many of the IMPROVE sites are mountainous sites and the associated upslope flow is difficult to represent in a coarse-resolution model like the GEOS-Chem model used in this study.

\section{Results and discussions}

\subsection{Seasonal and daily variations of surface $\mathrm{BC}$}

Figure 3 compares the seasonal variations of simulated and observed daily surface BC concentrations during 2006 at selected IMPROVE sites. Values shown are $24 \mathrm{~h}$ averages for every three days. Model results shown here are from simulations driven by GEOS-4 data with GFEDv2 8-day emissions unless stated otherwise. We sampled model results at the time and location of IMPROVE observations. In addition to a standard simulation where all emissions were included, we also conducted sensitivity simulations by shutting off separately sources of BC from North American anthropogenic emissions, Asian anthropogenic emissions, and global biomass burning emissions. The differences between results from the standard simulation and those from the sensitivity simulations therefore represent the contributions to surface $\mathrm{BC}$ concentrations from the aforementioned $\mathrm{BC}$ source types and source regions. These relative contributions are also shown in Fig. 3. Table 1 is a summary of the statistical comparisons of model versus observed surface BC concentrations at the IMPROVE sites examined here. GEOS-Chem $\mathrm{BC}$ reproduces both the synoptic variability and magnitudes of surface BC concentrations at sites downwind of but near urban centers. Figure 3 includes two such sites, Meadview, AZ (36. $\left.0^{\circ} \mathrm{N}, 114.1^{\circ} \mathrm{W}, 0.90 \mathrm{~km}\right)$ (Fig. 3a) and San Gabriel, CA $\left(34.3^{\circ} \mathrm{N}, 118.0^{\circ} \mathrm{W}, 1.79 \mathrm{~km}\right)$ (Fig. 3b). Meadview is about 100 miles to the east of Las Vegas. The San Gabriel site is on the northern edge of the Los Angeles Basin. The correlation coefficients $(r)$ between model and observed surface BC concentrations are 0.45 and $0.55(p<0.001)$ for Meadview and for San Gabriel. North American anthropogenic emissions account for $\sim 98 \%$ of the annual mean BC concentrations at the two sites. North American anthropogenic emissions thus dominate at these sites as seen in the model results. The agreements at these sites indicate that North American anthropogenic $\mathrm{BC}$ emissions in the model are reasonably prescribed.

Both the observations and model results show broad maxima of surface $\mathrm{BC}$ concentrations during summer and fall at some sea-level sites (e.g. Fig. 3c) and at elevated sites (Fig. 3d-p). The seasonal variations of BC vary considerably from site to site. Some of the highest BC concentrations are seen during August and September at most of the sites. Relatively small fires (in terms of BC emissions) are apparent in late April and early May at sites such as Kalmiopsi, OR $\left(42.6^{\circ} \mathrm{N}, 124.1^{\circ} \mathrm{W}, 0.08 \mathrm{~km}\right)$ and Three Sisters, OR $\left(44.3^{\circ} \mathrm{N}, 122.0^{\circ} \mathrm{W}, 0.89 \mathrm{~km}\right)$. At the $0-1 \mathrm{~km}$ altitude range, model results reproduce largely the peaks of BC concentrations observed during the fire season at some IMPROVE sites, e.g. Kalmiopsi, OR $(r=0.59, p<0.001)$ and North Cascades, WA $\left(48.7^{\circ} \mathrm{N}, 121.1^{\circ} \mathrm{W}, 0.57 \mathrm{~km}, r=0.54\right.$, $p<0.001)$. At elevated sites, however, model results significantly underestimate surface BC concentrations often by a factor of at least two during summer and fall (Fig. 3ep). For instance, model results are biased low by $59 \%$ at Hells Canyon, OR $\left(45.0^{\circ} \mathrm{N}, 116.8^{\circ} \mathrm{W}, 0.66 \mathrm{~km}\right)$ and $74 \%$ at Pasayten, WA $\left(48.4^{\circ} \mathrm{N}, 119.9^{\circ} \mathrm{W}, 1.63 \mathrm{~km}\right)$. The discrepancies exist not only in the magnitudes of $\mathrm{BC}$ concentrations but also in the timing of the enhanced $\mathrm{BC}$ concentrations. In particular, some of the observed large enhancements due to biomass burning during June and July are completely missing in the model results. For example, at Hells Canyon, OR and Three Sisters, OR, observed large enhancements to the 

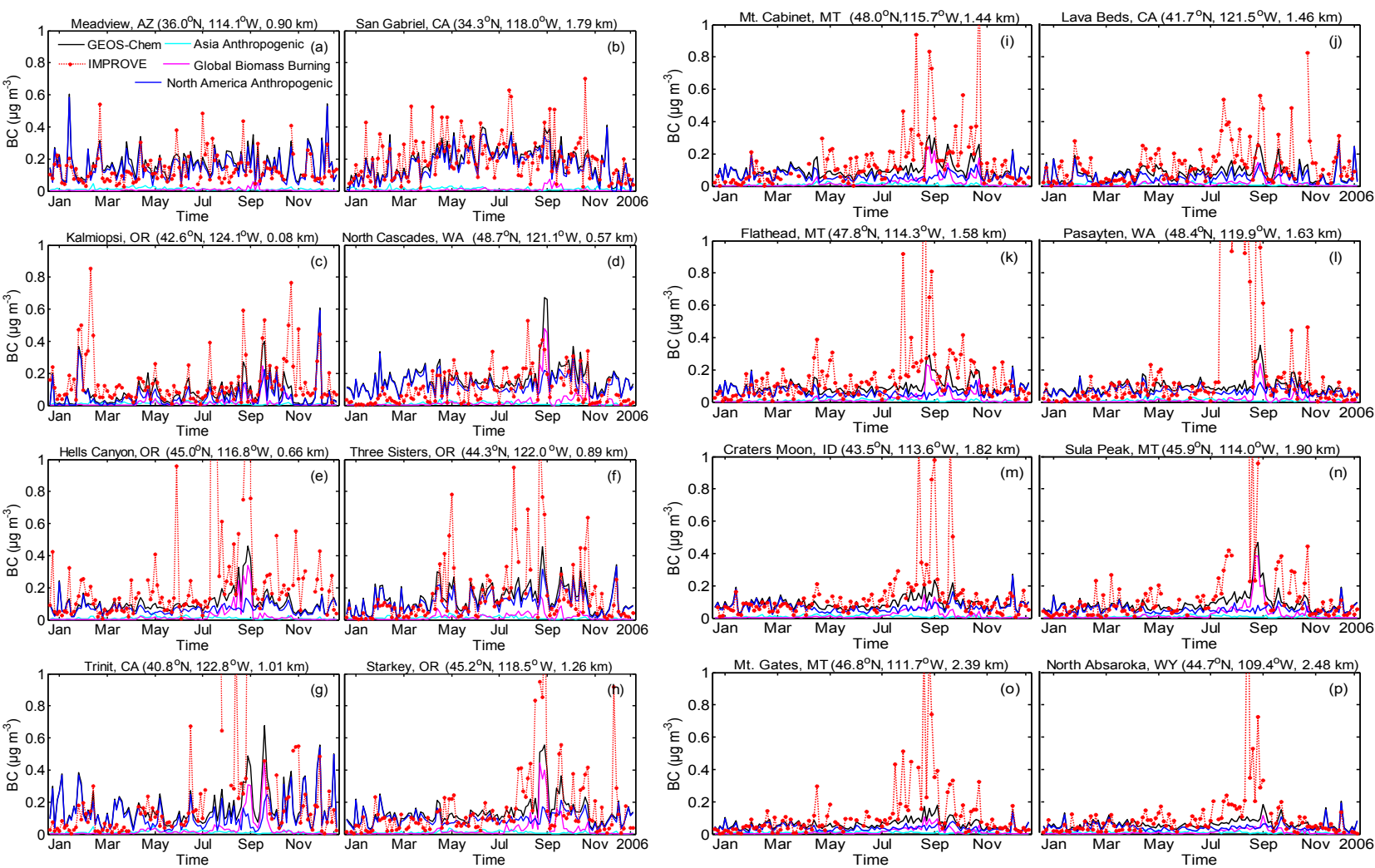

Fig. 3. (a-p) Simulated (black line) and observed (red line) daily surface BC concentrations at representative IMPROVE sites (Fig. 1) in 2006. Values shown are daily averages for every three days. Simulations are driven by GEOS-4 reanalysis data and with GFEDv2 8-day emissions. Model results are sampled at the time and location of IMPROVE observations. Also shown are relative contributions to surface $\mathrm{BC}$ concentrations from Asian anthropogenic emissions (green line), global biomass burning emissions (pink line), and North American anthropogenic emissions (blue line).

surface BC are in middle July. Though simulated BC concentrations show small yet significant relative enhancements, the large peaks of simulated BC concentrations do not occur until September. The discrepancies are larger at the $1-3 \mathrm{~km}$ altitude range. The simulated $\mathrm{BC}$ concentrations at Flathead, MT $\left(47.8^{\circ} \mathrm{N}, 114.3^{\circ} \mathrm{W}, 1.58 \mathrm{~km}\right)$, Craters Moon, ID $\left(43.5^{\circ} \mathrm{N}, 113.6^{\circ} \mathrm{W}, 1.82 \mathrm{~km}\right)$, and Mt. Gates, MT $\left(46.8^{\circ} \mathrm{N}\right.$, $\left.111.7^{\circ} \mathrm{W}, 2.39 \mathrm{~km}\right)$ are biased low by a factor of three or more. Part of the discrepancies is because of the model resolution, which is too coarse to resolve fine regional distributions of BC. As widely pointed out in previous studies, comparing localized observations with model results that are representative of a much larger area is inherently problematic. There is another compounding factor that contributes to the aforementioned discrepancies, especially at elevated mountainous sites. In the standard GEOS-Chem simulation of $\mathrm{BC}$ as reported here, biomass burning emissions are uniformly distributed throughout the planetary boundary with the assumption that boundary layer mixing is efficient. For elevated mountainous sites, the surface $\mathrm{BC}$ concentrations are often influenced more by up-slope flow than boundary layer mixing; the latter is not resolved explicitly in coarseresolution global models like the GEOS-Chem model used in this study.

Figure 4 compares the observed and model simulated daily surface BC concentrations averaged for sites at the altitude ranges $0-1,1-2,2-3$, and $3-4 \mathrm{~km}$, respectively. Model results shown here are from simulations driven by GEOS-4 meteorological data and with GFEDv2 8-day emissions. Again, Fig. 4 shows significantly underestimated surface BC concentrations in the model during summer and fall, especially at the $1-2 \mathrm{~km}$ and $2-3 \mathrm{~km}$ altitudes. Model results are biased low by $37 \%$ at $1-2 \mathrm{~km}(r=0.57, p<0.001)$ and $38 \%$ at $2-3 \mathrm{~km}(r=0.50, p<0.001)$ altitude ranges (Table 1). The contributions to surface BC concentrations in the WUS from North American anthropogenic emissions show rather small variations throughout the year at all four altitude ranges. Figures 3 and 4 also show small yet significant relative enhancements of $\mathrm{BC}$ concentrations (up to $50 \%$ ) during February to March and April to early May. These enhancements are particularly evident at the $0-1$ and $1-2 \mathrm{~km}$ altitude ranges and to a lesser degree at $2-3 \mathrm{~km}$. Our model results show 
Table 1. GEOS-Chem simulated and IMPROVE observed mean surface BC concentrations, model biases, and correlation coefficients between model results and observations (Figs. 3, 4 and 8).

\begin{tabular}{lcccc}
\hline Figure & $\begin{array}{c}\text { Obs. mean } \\
\left(\mu \mathrm{g} \mathrm{m}^{-3}\right)\end{array}$ & $\begin{array}{c}\text { Model mean } \\
\left(\mu \mathrm{g} \mathrm{m}^{-3}\right)\end{array}$ & $\begin{array}{c}\text { Model bias }(\%) \\
(\text { Model-Obs. }) / \text { Obs. }\end{array}$ & $\begin{array}{c}r \\
(p<0.001)\end{array}$ \\
\hline 3a & 0.137 & 0.168 & 22.63 & 0.45 \\
3b & 0.210 & 0.187 & -10.95 & 0.55 \\
3c & 0.148 & 0.082 & -44.59 & 0.59 \\
3d & 0.108 & 0.166 & 53.70 & 0.54 \\
3e & 0.255 & 0.105 & -58.82 & 0.52 \\
3f & 0.160 & 0.138 & -13.75 & 0.59 \\
3g & 0.301 & 0.170 & -43.52 & $0.16(p=0.063)$ \\
\hline 3h & 0.161 & 0.139 & -13.66 & 0.72 \\
3i & 0.158 & 0.105 & -33.54 & 0.53 \\
3j & 0.135 & 0.081 & -40.00 & 0.51 \\
3k & 0.152 & 0.094 & -38.16 & 0.33 \\
31 & 0.366 & 0.095 & -74.04 & $0.13(p=0.182)$ \\
\hline 3m & 0.137 & 0.093 & -32.12 & 0.51 \\
3n & 0.163 & 0.086 & -47.24 & 0.42 \\
3o & 0.121 & 0.062 & -48.76 & 0.71 \\
3p & 0.107 & 0.062 & -42.06 & 0.31 \\
\hline 4a & 0.173 & 0.139 & -19.65 & 0.50 \\
4b & 0.175 & 0.111 & -36.57 & 0.57 \\
4c & 0.114 & 0.071 & -37.72 & 0.50 \\
4d & 0.088 & 0.046 & -47.73 & 0.49 \\
\hline 8a GEOS-5 & 0.173 & 0.170 & -1.73 & 0.38 \\
8b GEOS-5 & 0.175 & 0.113 & -35.43 & 0.62 \\
8c GEOS-5 & 0.114 & 0.069 & -39.47 & 0.61 \\
8d GEOS-5 & 0.088 & 0.042 & -52.27 & 0.51 \\
\hline
\end{tabular}

that these enhancements are dominated by North American anthropogenic emissions but with significant contributions from Asian anthropogenic emissions. This relatively large Asian influence during this time of the year is consistent with our understanding that the transpacific transport of Asian pollution is strongest in spring (Jacob et al., 2010; Report of National Research Council, 2009; Liu et al., 2003, 2005; Jaffe et al., 2003, 2005).

\subsection{BC correlations with $\mathrm{K}, \mathrm{K} / \mathrm{S}$, and dust}

In this Section we examine the correlations between surface $\mathrm{BC}$ and $\mathrm{K}, \mathrm{K} / \mathrm{S}$, and soil dust to further verify the large influence of biomass burning on the surface $\mathrm{BC}$ concentrations in the WUS during summer and fall. As an example, Fig. 5 shows time series of observed surface concentrations of BC and $\mathrm{K}$ as well as K/S ratios at Flathead, MT. The large BC concentration peaks $\left(0.4-1 \mu \mathrm{g} \mathrm{m}^{-3}\right)$ during August-October are strongly correlated with either high $\mathrm{K}$ concentrations (up to $0.3 \mu \mathrm{g} \mathrm{m}^{-3}$ ) or high $\mathrm{K} / \mathrm{S}$ ratios (up to 0.9 ) or both. The correlation coefficients are 0.95 between observed surface concentrations of $\mathrm{BC}$ and $\mathrm{K}$ and 0.61 between $\mathrm{BC}$ concentrations and K/S ratios during August-October $(p<0.001)$. We find similar strong correlations during the summer and fall fire season at most of the mountainous sites (not shown). These correlations suggest that biomass burning emissions dominate the broad maxima of surface BC concentrations in summer and fall. That biomass burning emissions are the dominant source to surface BC concentrations in the WUS mountain ranges during summer and fall is consistent with our model results (Sect. 3.1).

Also shown in Fig. 5 are time series of IMPROVE surface soil dust concentrations. The relatively high surface $\mathrm{BC}$ concentrations (up to $0.4 \mu \mathrm{g} \mathrm{m}^{-3}$ ) during middle March and April to early May correspond with high soil dust concentrations (up to $2 \mu \mathrm{g} \mathrm{m}^{-3}$ ) and relatively low $\mathrm{K}$ concentrations and $\mathrm{K} / \mathrm{S}$ ratios. The correlation coefficient is 0.74 between observed surface concentrations of BC and soil during March-May $(p<0.001)$. As discussed in Sect. 2.1 , the strong BC-soil dust correlations thus indicate significant anthropogenic contributions to the surface $\mathrm{BC}$ at the site during spring. Our examination of BC-soil dust correlations at the other IMPROVE sites shows similar results (not shown). The significant springtime anthropogenic contributions to the surface BC in the WUS mountain ranges are in agreements with our model results that show dominant contributions from North American anthropogenic emissions (Sect. 3.1). 

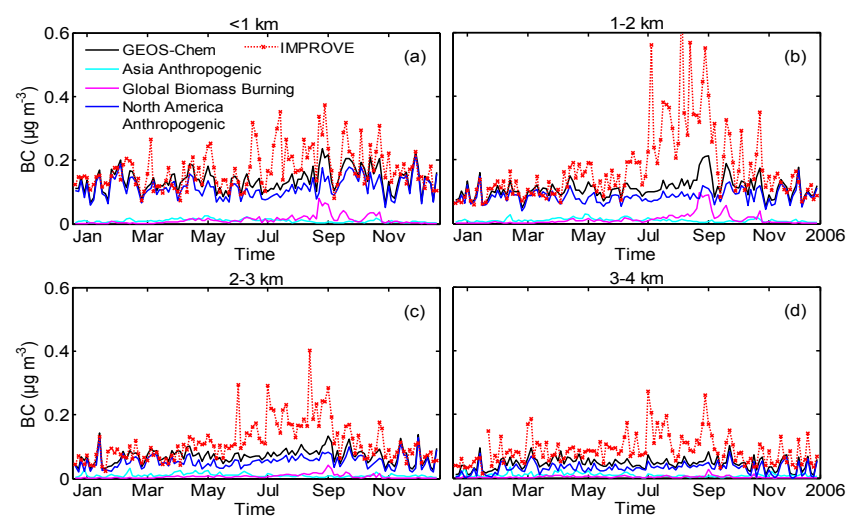

Fig. 4. Simulated (black line) and observed (red dots) daily surface BC concentrations at IMPROVE sites (Fig. 1) for 2006, averaged for four altitude ranges: (a) below $1 \mathrm{~km}$ (18 sites), (b) $1-2 \mathrm{~km}(30$ sites), (c) $2-3 \mathrm{~km}$ (18 sites), and (d) above $3 \mathrm{~km}$ (3 sites). Simulations are driven by GEOS-4 reanalysis data and with GFEDv2 8-day emissions. Also shown are simulated relative contributions to surface BC concentrations from Asian anthropogenic emissions (green line), global biomass burning emissions (pink line), and North American anthropogenic emissions (blue line).

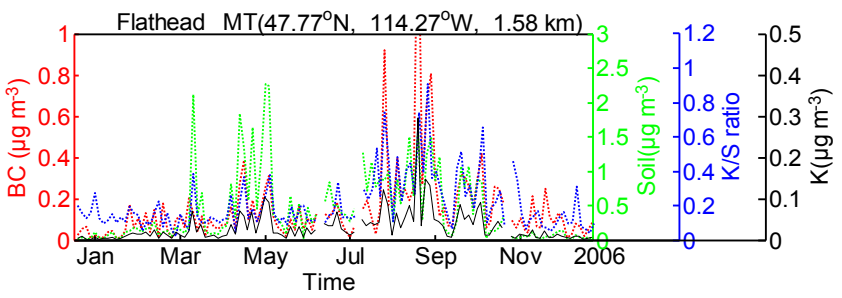

Fig. 5. Daily surface concentrations of BC (red line), soil (green line), potassium (K, black line), and potassium to sulfur $(\mathrm{K} / \mathrm{S})$ ratio (blue line) at IMPROVE site Flathead, MT $\left(47.8^{\circ} \mathrm{N}, 114.3^{\circ} \mathrm{W}\right.$, $1.58 \mathrm{~km}$ ) for 2006.

As discussed in Sect. 3.1, North American anthropogenic emissions prescribed in the model appear to be reasonable. The broad maxima of surface BC concentrations in the WUS mountain ranges during summer and fall are dominated by biomass burning emissions. Thus the large discrepancies between our model results and the observations in the summer and fall fire season can be attributed in large part to the biomass burning emissions of $\mathrm{BC}$ being underestimated in the model, likely by more than a factor of two. An ongoing analysis shows that GFEDv2 underestimates BC emissions not just in the WUS but rather globally (Y. Chen et al., manuscript in preparation, UC Irvine). The GFEDv3 inventory (van der Werf et al., 2010) that recently became publicly available, gives even lower total carbon hence BC emissions than GFEDv2 in the WUS. Many factors may have contributed to the underestimation, from burned area, fuel load estimate, to BC emission factors (van der Werf et al., 2010).
As such, the low bias may not be limited to the estimate of $\mathrm{BC}$ emissions but rather that of total carbon emissions hence other species in GFED. Yet another potentially important factor is the lack of detection of small-scale agriculture burnings (van der Werf et al., 2010; Korontzi et al., 2006). In addition, the discrepancies in the timing of the observed and simulated surface $\mathrm{BC}$ enhancements suggest that the uncertainties of biomass burning emissions of $\mathrm{BC}$ are not only in the magnitudes of fire emissions but also likely in the timing and location of fires.

\subsection{Sensitivity of surface BC to PBL height}

A previous study by Park et al. (2003) using the GEOS-Chem model driven by GEOS-3 reanalysis data estimated the contribution of Asian emissions to the surface $\mathrm{BC}$ concentrations in the US in 1998. Fire activities in temperate North America were considerably weaker in 1998 than in 2006 in terms of burned area (Giglio et al., 2010). Their model results showed very good agreements with IMPROVE observations of BC $\left(r^{2}>0.8\right)$ including those in the summer and fall fire season. Interannual biomass burning emissions in that study were from Duncan et al. (2003). To reconcile the apparent differences between results from our simulation driven by GEOS-4 data and those of Park et al. (2003), we conducted a simulation for 1998 using the same GEOS-Chem configurations, including GEOS-3 reanalysis data and the various emissions (biomass burning included), as used by Park et al. (2003) (the line "GEOS-3 Interannual" in Fig. 6). In addition, we also conducted a model simulation for the same year but driven by GEOS-4 data and with the same Duncan et al. (2003) biomass burning emissions as used by Park et al. (2003) (the line "GEOS-4 Interannual" in Fig. 6). Figure 6 compares the monthly mean surface BC concentrations for JuneDecember 1998 from these three simulations against IMPROVE observations at Mt. Rainier, WA $\left(46.8^{\circ} \mathrm{N}, 122.1^{\circ} \mathrm{W}\right.$, $0.44 \mathrm{~km}$ ) and Three Sisters, OR. Also shown in Fig. 6 are results from our standard model simulation driven by GEOS4 data and with GFEDv2 8-day biomass burning emissions (the line "GEOS-4 GFEDv2 8-day" in Fig. 6). We are able to reproduce the results reported by Park et al. (2003). The results from the simulation driven by GEOS-3 data are in good agreements with IMPROVE observations. The results from the two simulations driven by GEOS-4 data are very similar, despite the different biomass burning emissions used. However, the results from both of these simulations show considerably lower surface BC concentrations than those from the simulation driven by GEOS-3 meteorological data and from IMPROVE observations.

Part of the discrepancy seen in Fig. 6 can be attributed to the different planetary boundary layer (PBL) heights. We compare PBL heights (above model ground level instead of sea-level) from GEOS-3 and GEOS-4 against those from NCEP North American Regional Reanalysis data (NARR) (Mesinger et al., 2006; data available at http://www.esrl. 


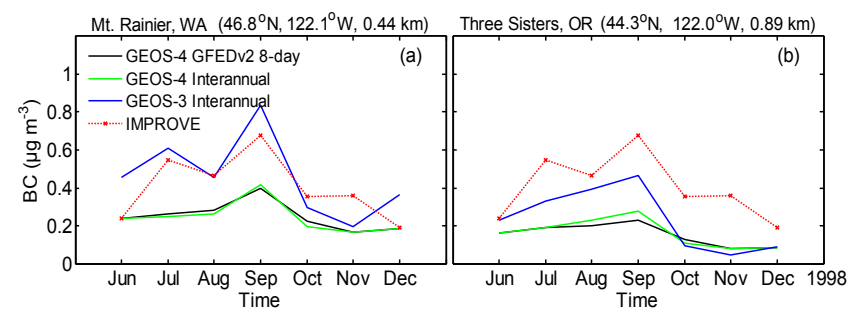

Fig. 6. Monthly mean surface $\mathrm{BC}$ concentrations from June to December 1998 at (left) Mt. Rainier, WA $\left(46.8^{\circ} \mathrm{N}, 122.1^{\circ} \mathrm{W}, 0.44 \mathrm{~km}\right)$ and (right) Three Sisters, OR $\left(44.3^{\circ} \mathrm{N}, 122.0^{\circ} \mathrm{W}, 0.89 \mathrm{~km}\right)$. Red lines: IMPROVE observations; black lines: model driven by GEOS-4 data and with GFEDv2 8-day emissions; green lines: model driven by GEOS-4 reanalysis data and with Duncan et al. (2003) interannual biomass burning emissions; blue lines: model driven by GEOS-3 reanalysis data and with Duncan et al. (2003) interannual biomass burning emissions.

noaa.gov/psd/cgi-bin/data/narr/plothour.pl). The NARR data have a horizontal resolution of $32 \mathrm{~km}$ and a temporal resolution of three hours. To compare with NARR data, we extracted PBL heights at 14:00 LT at the IMPROVE sites from all three datasets. Figure 7 shows as an example the comparison for August-September 1998 for Mt. Rainier. PBL heights are considerably lower in GEOS-3 than in NARR. In contrast, GEOS-4 PBL heights are in good agreement with NARR data. Other IMPROVE sites show similar comparisons. It is thus clear that the unusually shallow boundary layer in GEOS-3 data partly results in artificially high surface $\mathrm{BC}$ concentrations in the model simulation driven by GEOS3 reanalysis data hence a false good agreement with IMPROVE observations. Because the US fossil fuel emissions of BC prescribed in GEOS-Chem are reasonable (Sect. 3.1), our model simulations driven by GEOS-4 data therefore suggest that biomass burning emissions of $\mathrm{BC}$ were likely significantly underestimated in Park et al. (2003), too.

We conducted an additional GEOS-Chem simulation for 2006, driven by GEOS-5 meteorological fields and with GFEDv2 8-day biomass burning emissions. The results are compared against IMPROVE observations and those from the standard simulation. Figure 8 shows surface BC concentrations from model results and IMPROVE observations, averaged for IMPROVE sites at the 0-1, 1-2, 2-3, and 3$4 \mathrm{~km}$ altitude ranges. During the fire season, surface BC concentrations from the simulation driven by GEOS-5 data increase considerably (relative to the standard simulation), especially at the $0-1 \mathrm{~km}$ altitude ranges thereby improving the comparisons (Fig. 8a). Part of this improvement is because of the better-resolved boundary layer in GEOS-5 than in both GEOS-4 and GEOS-3 (Sect. 2.2). The two model simulations driven by GEOS- 5 and by GEOS-4 data show very similar results at the higher altitude ranges. Both model results are still biased low, though, particularly at the 1-2 and $2-3 \mathrm{~km}$ altitudes during the fire season (Fig. 8b, c). The

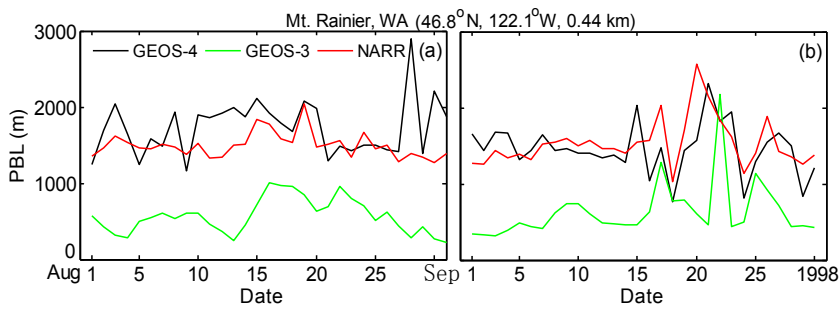

Fig. 7. Planetary boundary layer heights for (left) August and (right) September 1998 at Mt. Rainier, WA $\left(46.8^{\circ} \mathrm{N}, 122.1^{\circ} \mathrm{W}, 0.44 \mathrm{~km}\right)$ (black line, GEOS-4; green line, GEOS-3; red line, North American Regional Reanalysis (NARR; available at http://www.esrl.noaa.gov/ psd/cgi-bin/data/narr/plothour.pl). Values are for 14:00 LT (Daylight savings time).
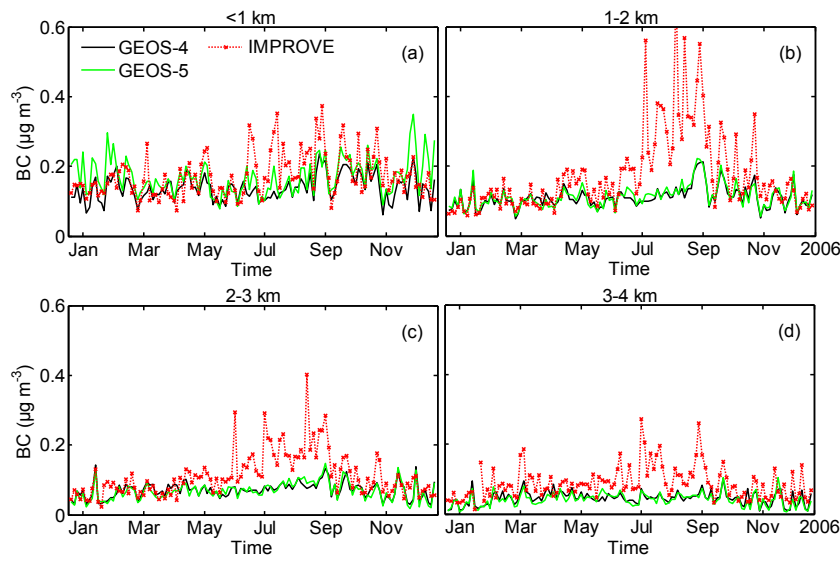

Fig. 8. (a-d) Same as Fig. 4, but from simulations driven by GEOS4 (black line) and GEOS-5 (green line) reanalysis data and with GFEDv2 8-day emissions.

largest discrepancies are seen at $1-2 \mathrm{~km}$. The correlation coefficients between simulated BC concentrations with observations show slightly improvement at $1-3 \mathrm{~km}(r=0.62$, $p<0.001)$. The increased correlation coefficients imply that the variations of simulated BC driven by GEOS- 5 data show slightly improved comparison with the observations at sites in the $1-3 \mathrm{~km}$ altitude range.

Again, we compare PBL heights between GEOS-4 and GEOS-5 at IMPROVE sites. As an example, Fig. 9 compares the PBL heights from GEOS-4 and GEOS-5 with NARR data at Mt. Rainier for August and September 2006. Both GEOS4 and GEOS-5 PBL heights are in reasonable agreements with NARR data. These results imply that both GEOS-4 and GEOS-5 meteorological fields are better suited than GEOS-3 for the simulation of BC in GEOS-Chem.

\subsection{Sensitivity of surface $\mathrm{BC}$ to improved and finer temporally resolved biomass burning emissions}

Giglio et al. (2006) showed that the burned area estimates in GFEDv2 had low biases of $17 \%$ in Alaska and $30 \%$ in 


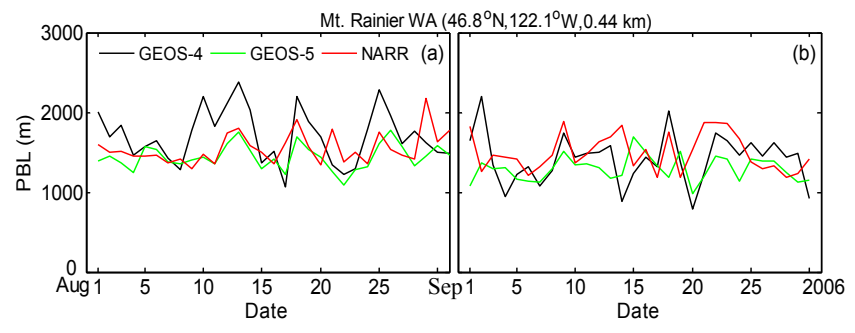

Fig. 9. Same as Fig. 7, but from GEOS-4 (black line), GEOS-5 (green line), and NARR (red line) for 2006.

Western Canada. In a recent modeling study using GEOSChem and GFEDv2 emissions, Chen et al. (2009) scaled up GFEDv2 emissions of carbon monoxide (CO) and $\mathrm{BC}$ by $20 \%$ over North America to correct for these low biases. Our sensitivity simulations showed that fires in the WUS were the major contributor of biomass burning emissions to the surface $\mathrm{BC}$ concentrations in the WUS mountain ranges (not shown) during the summer and fall fire season. Biomass burning emissions in the WUS account for $\sim 75 \%$ of total biomass burning contribution to the surface BC concentrations during summer and fall. We conducted a sensitivity GEOS-Chem simulation driven by GEOS-4 data where we increased the GFEDv2 8-day emissions by $50 \%$ over the WUS. Figure 10 compares the results with IMPROVE observations. This significantly improves model comparisons with observations during the fire season. Simulated surface $\mathrm{BC}$ concentrations show near linear enhancement relative to those from the standard simulation. The largest increases are at the $1-2 \mathrm{~km}$ altitude ranges in the summer and fall fire season (Fig. 10b). The increased emissions have rather small impacts on the surface $\mathrm{BC}$ concentrations at the 0 $1 \mathrm{~km}$ (Fig. 10a) and 3-4 km (Fig. 10d) altitudes. However, simulated BC concentrations are still significantly lower than IMPROVE observations. Clearly not only the total biomass burning emissions of $\mathrm{BC}$ as prescribed in the model is likely too low but also the spatiotemporal distributions of the emissions are less than accurate. Small fires are likely a major source of uncertainty in the estimates of biomass burning emissions of BC (Giglio et al., 2006, 2009, 2010). Since agricultural burnings are usually small fires therefore difficult to detect from space, agricultural burnings may be another large uncertainty (van der Werf et al., 2010; Korontzi et al., 2006). Furthermore, that some fires were obscured by clouds or vegetation, or were not actively burning at the time of the satellite overpass introduces yet additional uncertainties (Giglio et al., 2009).

Chen et al. (2009) have also shown that finer temporally resolved biomass burning emissions had significant impacts on GEOS-Chem simulated surface $\mathrm{CO}$ and $\mathrm{BC}$ concentrations, especially in the biomass burning source regions in Alaska and Western Canada. To account for the strong diur-
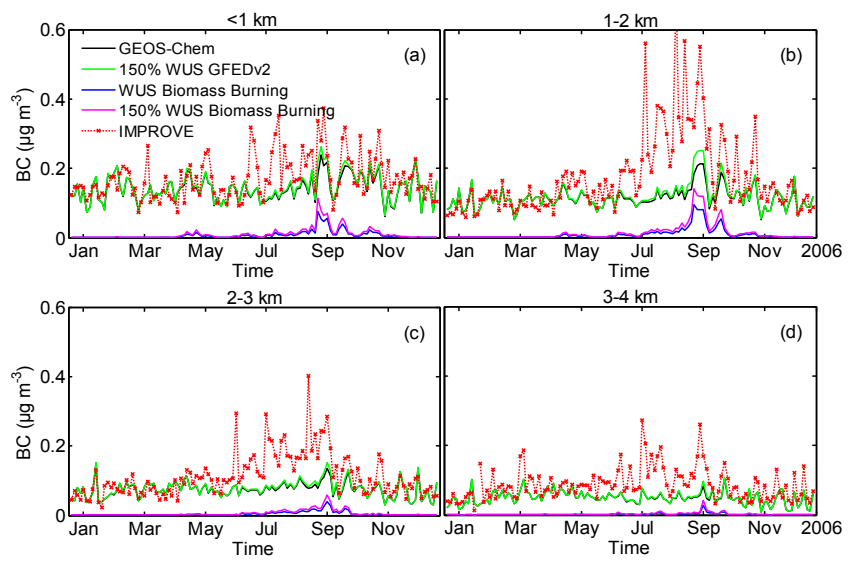

Fig. 10. (a-d) Same as Fig. 4, but from simulations with standard GFEDv2 8-day emissions (black line) and with GFEDv2 8day emissions increased by $50 \%$ (green line) over the WUS. Also shown are contributions to surface $\mathrm{BC}$ from biomass burning emissions (blue line) and $150 \%$ biomass burning emissions (pink line) over the WUS .

nal cycles of forest fires - peak burning typically occurs from 13:00 to 18:30 LT and distinctly earlier in heavily forested regions (Giglio et al., 2007), we started with the GFEDv2 8 -day emissions and applied diurnal cycles with a $3 \mathrm{~h}$ time step. The result is a GFEDv2 diurnal inventory with a 3hourly temporal resolution. The mean diurnal cycles were constructed based on the Automated Biomass Burning Algorithm (ABBA) active fire observations from the Geostationary Operational Environmental Satellites (GOES) (Chen et al., 2009). Additionally, the variations of synoptic weather conditions may influence forest fires and the associated emissions - high wind speed and less precipitation may enhance forest fires, for instance. It is thus essential to account for this synoptic variability in forest fires. Initial Spread Index (ISI: Van Wagner,1987) indicates the fire favorability of synoptic weather conditions and the expected rate of fire spread (Chen et al., 2009, and references therein). ISI was calculated to re-distribute emissions within each 8-day period using GEOS meteorological parameters including temperature, relative humidity, wind speed, and precipitation (Chen et al., 2009). Such synoptic, day-to-day variability was then superimposed onto the 3-hourly diurnal inventory. The resulting GFEDv2 synoptic inventory thus combined both diurnal and synoptic variations. In other words, the GFEDv2 synoptic inventory thus includes both diurnal and daily variability with a 3-hourly temporal resolution. We would like to point out that the GFEDv2 8-day inventory (and the synoptic and diurnal inventories as a result) likely already includes some synoptic variability. That is because the 8-day inventory was in part constrained by active fire counts, which are presumably influenced by synoptic weather conditions.

We conducted two simulations driven by GEOS-4 and by GEOS-5 reanalysis data, both with GFEDv2 synoptic 

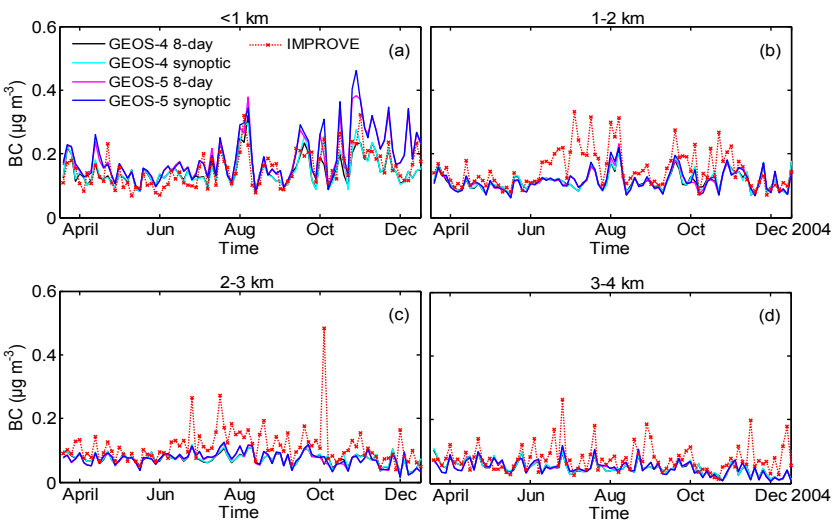

Fig. 11. (a-d) Same as Fig. 4, but for April-December 2004 and with GFEDv2 8-day emissions (black line, GEOS-4; pink line, GEOS-5) and GFEDv2 synoptic emissions (green line, GEOS-4; blue line, GEOS-5).

emissions. Additionally, we conducted two simulations driven by GEOS- 4 and by GEOS- 5 reanalysis data, but with GFEDv2 8-day emissions. All four simulations are for 2004, the year for which both GEOS-4 and GEOS-5 data are available to us. Also, the GFEDv2 synoptic emissions are available only for 2004 as of this study. Figure 11 compares the results with IMPROVE observations from April to December 2004. The correlation coefficients are summarized in Table 2. Since 2004 is a relatively weak fire year in terms of burned area in temperate North America (Giglio et al., 2010), the discrepancies between model results and IMPROVE observations are smaller in 2004 than in 2006. With the 3-hourly GFEDv2 synoptic emissions, the correlation coefficients between model results and observations show slight improvements at all altitudes. The largest improvements are seen at below $2 \mathrm{~km}$ altitudes, but model results still vastly underestimate surface BC concentrations during the fire season. Simulated surface $\mathrm{BC}$ concentrations show overall very similar variability between model results using the 3-hourly synoptic and the 8-day GFEDv2 inventories. This similarity implies that the variation of the surface $\mathrm{BC}$ at the mountainous IMPROVE sites examined here is largely driven by the synoptic (rather than the 3-houly) variability and transport of the fire emissions and that many of the sites are not directly located in the fire emission source regions. That, and the fact that forest fires usually last on synoptic and longer time scales, lead us to conclude that the model results with the GFEDv2 8-day inventory are proper for comparison with IMPROVE (every 3 days) daily data. Results from the simulation driven by GEOS-5 data and with GFEDv2 synoptic emissions are in slightly better agreement with IMPROVE observations during summer and fall. The results from the simulations driven by GEOS- 4 and by GEOS- 5 data, on average, are comparable and almost indistinguishable.
Table 2. Correlation coefficients between GEOS-Chem simulated and IMPROVE observed surface BC concentrations (Fig. 11).

\begin{tabular}{ccccc}
\hline \multirow{2}{*}{ Figure } & \multicolumn{2}{c}{ GFEDv2 8-day } & \multicolumn{2}{c}{ GFEDv2 synoptic } \\
\cline { 2 - 5 } & GEOS-4 & GEOS-5 & GEOS-4 & GEOS-5 \\
\hline $11 \mathrm{a}$ & 0.68 & 0.68 & 0.71 & 0.70 \\
$11 \mathrm{~b}$ & 0.33 & 0.30 & 0.34 & 0.31 \\
$11 \mathrm{c}$ & 0.31 & 0.41 & 0.37 & 0.46 \\
$11 \mathrm{~d}$ & 0.11 & 0.17 & 0.12 & 0.18 \\
\hline
\end{tabular}

\subsection{Sensitivity of surface BC to vertically injected biomass burning emissions}

Ample evidence has shown that biomass burning smoke plumes can be injected into the free troposphere (Mims et al., 2010; Kahn et al., 2008). Modeling studies also showed that vertically injected biomass burning emissions can significantly improve model comparisons with observations (Leung et al., 2007; Turquety et al., 2007). We are thus motivated by these studies to include the vertical injection of biomass burning emissions to above the boundary layer. It is conceivable that the vertical injection can lead to increased surface BC concentrations at elevated IMPROVE sites in the WUS, especially those sites that are downwind of but near fire regions. To investigate the impact of smoke plume vertical injection on surface $\mathrm{BC}$, we conducted two simulations with vertical injection of GFEDv2 8-day emissions. In the first simulation, GFEDv2 emissions were evenly distributed throughout the boundary layer. Obviously, this approach underestimates emissions injected into the free troposphere. In the second simulation, GFEDv2 emissions were uniformly (in mass mixing ratio) distributed throughout the tropospheric column up to $200 \mathrm{hPa}$. This approach represents an extreme scenario in which certain percentages of emissions from each forest fires are injected to the middle and upper troposphere. As expected, the simulated summer-fall surface BC concentrations from the second simulation show significant decreases compared with the first simulation at sites below $2 \mathrm{~km}$ (not shown) simply because of more emissions are injected to above the boundary layer. However, we find that the inclusion of plume vertical injection, on average, has relatively small impact on the simulated surface BC concentrations in the WUS mountain ranges during the fire season (not shown). This likely is because biomass burning emissions in the model are too low to show significant improvements.

\section{Summary and conclusions}

We have used a global 3-D chemical transport model driven by assimilated meteorological data (GEOS-Chem) to examine the sources of the surface black carbon (BC) in the Western United States (WUS) mountain ranges. We 
conducted simulations of $\mathrm{BC}$ for 2006 with $2^{\circ} \times 2.5^{\circ}$ horizontal resolution and compared model results to surface BC concentrations observed from the IMPROVE network. Sensitivity simulations were used to estimate the relative contributions from North American anthropogenic emissions, Asian anthropogenic emissions, and global biomass burning emissions to the surface BC concentrations in the WUS.

Observed concentrations of $\mathrm{BC}$ over the WUS showed strong enhancements during summer and fall of 2006. Observed concentrations of potassium and potassium to sulfur ratio, both tracers of biomass burning, indicated that these enhancements of $\mathrm{BC}$ concentrations were largely influenced by fire emissions. Model results were strongly sensitive to the assimilated meteorological observations, particularly the boundary layer schemes in the assimilation systems used to generate these meteorological data. The unusually shallow planetary boundary layer in GEOS-3 significantly and artificially increased model surface BC concentrations in the WUS. In contrast, model simulations driven by GEOS-4 and GEOS-5 meteorological observations with reasonable boundary layer heights, showed significantly lower surface $\mathrm{BC}$ concentrations. Observed $\mathrm{BC}$ concentrations during the summer and fall fire season were often a factor of two higher than the corresponding model results from simulations driven by GEOS-4 and GEOS-5 meteorological data. Largest discrepancies were seen at elevated mountainous sites (above $1 \mathrm{~km}$ altitude). Improved temporal variation including diurnal and synoptic variability and plume vertical injection in the biomass burning emission inventory were found to have relatively small impact on the simulated surface BC concentrations at the mountainous IMPROVE sites during the fire season.

Surface BC concentrations in the WUS were dominated by North American anthropogenic emissions year-around. Transpacific transport of Asian anthropogenic emissions became more important with increasing altitude and accounted for about $28 \%$ of surface BC concentrations in winter and $24 \%$ in spring at the $3-4 \mathrm{~km}$ altitude range. The large low bias of model results during summer and fall was a result of the low biomass burning emissions of $\mathrm{BC}$ used in the model. Biomass burning emissions contributed about 14$20 \%$ at the $1-2 \mathrm{~km}$ altitude range to surface $\mathrm{BC}$ concentrations during summer and fall, but these estimates were likely biased low by a factor of two. Biomass burning emissions are most important at the $1-2 \mathrm{~km}$ altitude range in the WUS. Our results so far have shown that, the contributions from global biomass burning emissions are significantly underestimated in our model, likely by more than a factor of two during summer and fall. Park et al. (2003) showed that annually about $30 \%$ of surface BC concentrations in the US were from biomass burning. It is likely that their estimate is biased low, too. Recent studies have projected increased fire activity in the WUS in the 21st century (Spracklen et al., 2009; Westerling and Bryant, 2008), which portend to even larger contributions from biomass burning to BC in the WUS.
Acknowledgements. This research was supported in part by NASA grants NNX09AF07G and NNX08AF64G from the Atmospheric Chemsitry Modeling and Analysis Program (ACMAP). The GEOS-Chem model is managed by the Atmospheric Chemistry Modeling group at Harvard University with support from the NASA ACMAP program. We thank Hongyu Liu and Yufang Jin for helpful discussions.

Edited by: D. Spracklen

\section{References}

Allen, D. J., Rood, R. B., Thompson, A. M., and Hudson, R. D.: Three-dimensional ranon 222 calculations using assimilated metrological data and a convective mixing algorithm, J. Geophys. Res., 101, 6871-6881, 1996a.

Allen, D. J., Kasibhatla, P., Thompson, A. M., Rood, R. B., Doddridge, B. G., Pickering, K. E., Hudson, R. D., and Lin, S.J.: Transport-induced interannual variability of carbon monoxide determined using a chemistry and transport model, J. Geophys. Res., 101, 28655-28669, 1996 b.

Arakawa, A. and Schubert, W. H.: Interaction of a cumulus cloud ensemble with the large-scale environment, Part I, J. Atmos. Sci., 31, 674-701, 1974.

Bey, I., Jacob, D. J., Yantosca, R. M., Logan, J. A., Field, B. D., Fiore, A. M., Li, Q., Liu, H.-Y., Mickley, L. J., and Schultz, M. G.: Global modeling of tropospheric chemistry with assimilated meteorology: Model description and evaluation, J. Geophys. Res., 106, 23073-23095, 2001.

Bond, T. C. and Sun, H.: Can reducing black carbon emissions counteract global warming?, Environ. Sci. Technol., 39, 59215926, 2005.

Bond, T. C., Streets, D. G., Yarber, K. F., Nelson, S. M., Woo, J.H., and Klimont, Z.: A technology-based global inventory of black and organic carbon emissions from combustion, J. Geophys. Res., 109, D14203, doi:10.1029/2003JD003697, 2004.

Bond, T. C., Bhardwaj, E., Dong, R., Jogani, R., Jung, S., Roden, C., Streets, D. G., and Trautmann, N. M.: Historical emissions of black and organic carbon aerosol from energy-related combustion, 1850-2000, Global Biogeochem. Cy., 21, GB2018, doi:10.1029/2006GB002840, 2007.

Chen, Y., Li, Q., Randerson, J. T., Lyons, E. A., Kahn, R. A., Nelson, D. L., and Diner, D. J.: The sensitivity of CO and aerosol transport to the temporal and vertical distribution of North American boreal fire emissions, Atmos. Chem. Phys., 9, 6559-6580, doi:10.5194/acp-9-6559-2009, 2009.

Chin, M., Ginoux, P., Kinne, S., Torres, O., Holben, B. N., Duncan, B. N., Martin, R. V., Logan, J. A., Higurashi, A., and Nakajima, T.: Tropospheric aerosol optical thickness from the GOCART model and comparisons with satellite and sun photometer measurements, J. Atmos. Sci., 59, 461-483, 2002.

Chin, M., Diehl, T., Ginoux, P., and Malm, W.: Intercontinental transport of pollution and dust aerosols: implications for regional air quality, Atmos. Chem. Phys., 7, 5501-5517, doi:10.5194/acp7-5501-2007, 2007.

Chow, J. C., Watson, J. G., Pritchett, L. C., Pierson, W. R., Frazier, C. A., and Purcell, R. G.: The DRI thermal/optical reflectance carbon analysis system: Description, evaluation, and 
applications in US air quality studies, Atmos. Environ., 27, 1185-1201, 1993.

Chow, J. C., Watson, J. G., Chen, L. W. A., Arnott, W. P., and Moosmuller, H.: Equivalence of elemental carbon by thermal/optical reflectance and transmittance with different temperature protocols, Environ. Sci. Technol., 38, 4414-4422, 2004.

Committee on the Significance of International Transport of Air Pollutants, National Research Council: Global Sources of Local Pollution: An assessment of long-range transport of key air pollutants to and from the United States, the National Academies Press, Washington, DC, 1-97, 2009.

Cooke, W. F., Liousse, C., Cachier, H., and Feichter, J.: Construction of a $1^{\circ} \times 1^{\circ}$ fossil fuel emission data set for carbonaceous aerosol and implementation and radiative impact in the ECHAM4 model, J. Geophys. Res., 104, 22137-22162, 1999.

Duncan, B. N., Martin, R. V., Staudt, A. C., Yevich, R., and Logan, J. A.: Interannual and seasonal variability of biomass burning emissions constrained by satellite observations, J. Geophys. Res., 108, D24100, doi:10.1029/2002JD002378, 2003.

Flanner, M. G., Zender, C. S., Randerson, J. T., and Rasch, P. J.: Present day climate forcing and response from black carbon in snow, J. Geophys. Res., 112, D11202, doi:10.1029/2006JD008003, 2007.

Flanner, M. G., Zender, C. S., Hess, P. G., Mahowald, N. M., Painter, T. H., Ramanathan, V., and Rasch, P. J.: Springtime warming and reduced snow cover from carbonaceous particles, Atmos. Chem. Phys., 9, 2481-2497, doi:10.5194/acp-9-24812009, 2009.

Giglio, L., van der Werf, G. R., Randerson, J. T., Collatz, G. J., and Kasibhatla, P.: Global estimation of burned area using MODIS active fire observations, Atmos. Chem. Phys., 6, 957974, doi:10.5194/acp-6-957-2006, 2006.

Giglio, L., Loboda, T., Roy, D. P., Quayle, B., and Justice, C. O.: An active-fire based burned area mapping algorithm for the MODIS sensor, Remote Sens. Environ., 113, 408-420, doi:10.1016/j.rse.2008.10.006, 2009.

Giglio, L., Randerson, J. T., van der Werf, G. R., Kasibhatla, P. S., Collatz, G. J., Morton, D. C., and DeFries, R. S.: Assessing variability and long-term trends in burned area by merging multiple satellite fire products, Biogeosciences, 7, 1171-1186, doi:10.5194/bg-7-1171-2010, 2010.

Hack, J. J.: Parameterization of moist convection in the NCAR community climate model (CCM2), J. Geophys. Res., 99, 55515568, doi:10.1029/93JD03478, 1994.

Hadley, O. L., Ramanathan, V., Carmichael, G. R., Tang, Y., Corrigan, C. E., Roberts, G. C., and Mauger, G. S.: Trans-Pacific transport of black carbon and fine aerosols $(D<2.5 \mu \mathrm{m})$ into North America, J. Geophys. Res., 112, D05309, doi:10.1029/2006JD007632, 2007.

Hansen, J. and Nazarenko, L.: Soot climate forcing via snow and ice albedos, P. Natl. Acad. Sci., 101, 423-428, 2004.

Hansen, J., Sato, M., Ruedy, R., Nazarenko, L., Lacis, A., Schmidt, G. A., Russell, G., Aleinov, I., Bauer, M., Bauer, S., Bell, N., Cairns, B., Canuto, V., Chandler, M., Cheng, Y., Del Genio, A., Faluvegi, G., Fleming, E., Friend, A., Hall, T., Jackman, C., Kelley, M., Kiang, N., Koch, D., Lean, J., Lerner, J., Lo, K., Menon, S., Miller, R., Minnis, P., Novakov, T., Oinas, V., Perlwitz, Ja., Perlwitz, Ju., Rind, D., Romanou, A., Shindell, D., Stone, P., Sun, S., Tausnev, N., Thresher, D., Wielicki, B., Wong, T., Yao,
M., and Zhang, S.: Efficacy of climate forcings, J. Geophys. Res., 110, D18104, doi:10.1029/2005JD005776, 2005.

Husar, R. B., Tratt, D. M., Schichtel, B. A., Falke, S. R., Li, F., Jaffe, D., Gassá, S., Gill, T., Laulainens, N. S., Lu, F., Reheis, M. C., Chun, Y., Westphal, D., Holben, B. N., Gueymard, C., McKendry, I., Kuring, N., Feldman, G. C., McClain, C., Frouin, R. J., Merrill, J., DuBois, D., Vignola, F., Murayama, T., Nickovic, S., Wilson, W. E., Sassen, K., Sugimoto, N., and Malm, W. C.: Asian dust events of April 1998, J. Geophys. Res, 106, 18317-18330, 2001.

Hwang, I. and Hopke, P. K.: Estimation of source apportionment and potential source locations of $\mathrm{PM}_{2.5}$ at a west coastal IMPROVE site, Atmos. Environ., 41, 506-518, 2007.

Intergovernmental Panel on Climate Change (IPCC): The Physical Science Basis, edited by: Solomon, S., Qin, D., Manning, M., Chen, Z., Marquis, M., Averyt, K. B., Tignor M., and Miller, H. L.: Contribution of Working Group I to the Fourth Assessment Report of the Intergovernmental Panel on Climate Change, Cambridge Univ. Press, Cambridge, UK, 2007.

Jacob, D. J., Crawford, J. H., Maring, H., Clarke, A. D., Dibb, J. E., Emmons, L. K., Ferrare, R. A., Hostetler, C. A., Russell, P. B., Singh, H. B., Thompson, A. M., Shaw, G. E., McCauley, E., Pederson, J. R., and Fisher, J. A.: The Arctic Research of the Composition of the Troposphere from Aircraft and Satellites (ARCTAS) mission: design, execution, and first results, Atmos. Chem. Phys., 10, 5191-5212, doi:10.5194/acp-10-5191-2010, 2010.

Jacobson, M. Z.: Strong radiative heating due to the mixing state of black carbon in atmospheric aerosols, Nature, 409, 695-697, 2001.

Jacobson, M. Z.: Climate response of fossil fuel and biofuel soot, accounting for soot's feedback to snow and sea ice albedo and emissivity, J. Geophys. Res., 109, D21201, doi:10.1029/2004JD004945, 2004.

Jaffe, D., McKendry, I., Anderson, T., and Price, H.: Six "new" episodes of trans-Pacific transport of air pollutants, Atmos. Environ., 37, 391-401, 2003.

Jaffe, D., Tamura, S., and Harris, J.: Seasonal cycle and composition of background fine particles along the west coast of the US, Atmos. Environ., 39, 297-306, 2005.

Jaffe, D., Hafner, W., Chand, D., Westerling, A., and Spracklen, D. Interannual variations in $\mathrm{PM}_{2.5}$ due to wildfires in the Western United States, Environ. Sci. Technol., 42, 2812-2818, 2008.

Kahn, R. A., Chen, Y., Nelson, D. L., Leung, F.-Y., Li, Q., Diner, D. J., and Logan, J. A.: Wildfire smoke injection heights: Two perspectives from space, Geophys. Res. Lett., 35, L04809, doi:10.1029/2007GL032165, 2008

Kim, E., Hopke, P. K., Kenski, D. M., and Koerber, M.: Sources of fine particles in a rural midwestern US area, Environ. Sci. Technol., 39, 4953-4960, 2005.

Korontzi, S., McCarty, J., Loboda, T., Kumar, S., and Justice, C.: Global distribution of agricultural fires in croplands from $3 \mathrm{yr}$ of Moderate Resolution Imaging Spectroradiometer (MODIS) data, Global Biogeochem. Cy., 20, GB2021, doi:10.1029/2005GB002529, 2006.

Langmann, B., Duncan, B., Textor, C., Trentmann, J., and van der Werf, G. R.: Vegetation fire emissions and their impact on air pollution and climate, Atmos. Environ., 43, 107-116, 2009.

Leung, F.-Y. T., Logan, J. A., Park, R., Hyer, E., Kasischke, E., Streets, D., and Yurganov, L.: Impacts of enhanced 
biomass burning in the boreal forests in 1998 on tropospheric chemistry and the sensitivity of model results to the injection height of emissions, J. Geophys. Res., 112, D10313, doi:10.1029/2006JD008132, 2007.

Lin, S.-J. and Rood, R. B.: Multidimensional flux-form semiLagrangian transport schemes, Mon. Weather Rev., 124, 20462070, 1996.

Liu, H., Jacob, D. J., Bey, I., and Yantosca, R. M.: Constraints from ${ }^{210} \mathrm{~Pb}$ and ${ }^{7} \mathrm{Be}$ on wet deposition and transport in a global threedimensional chemical tracer model driven by assimilated meteorological fields, J. Geophys. Res., 106, 12109-12128, 2001.

Liu, H., Jacob, D. J., Bey, I., Yantosca, R. M., Duncan, B. N., and Sachse, G. W.: Transport pathways for Asian pollution outflow over the Pacific: Interannual and seasonal variations, J. Geophys. Res., 108, D208786, doi:10.1029/2002JD003102, 2003.

Liu, J. F., Mauzerall, D. L., and Horowitz, L. W.: Analysis of seasonal and interannual variability in transpacific transport, J. Geophys. Res., 110, D04302, doi:10.1029/2004JD005207, 2005.

Malm, W. C., Sisler, J. F., Huffman, D., Eldred, R. A., and Cahill, T. A.: Spatial and seasonal trends in particle concentration and optical extinction in the United States, J. Geophys. Res., 99, 13471370, 1994.

Mesinger, F., Dimego, G., Kalnay, E., Mitchell, K., Shafran, P. C., Ebisuzaki, W., Jovic, D., Woollen, J., Rogers, E., Berbery, E. H., Ek, M. B., Fan, Y., Grumbine, R., Higgins, W., Li, H., Lin, Y., Manikin, G., Parrish, D., and Shi, W.: North American Regional Reanalysis: A long-term, consistent, high-resolution climate dataset for the North American domain, as a major improvement upon the earlier global reanalysis datasets in both resolution and accuracy, B. Am. Meteorol. Soc., 87, 343-360, doi:10.1175/BAMS-87-3-343, 2006.

Mims, S. R., Kahn, R. A., Moroney, C. M., Gaitley, B. J., Nelson, D. L., and Garay, M. J.: MISR Stereo Heights of Grassland Fire Smoke Plumes in Australia, Geosci. Remote Sens., 48, 25-35, 2010.

Moorthi, S. and Suarez, M. J.: Relaxed Arakawa-Schubert: A parameterization of moist convection for general circulation models, Mon. Weather Rev., 120, 978-1002, 1992.

Novakov, T., Kirchstetter, T. W., Sinton, J. E., Sathaye, J. A., Ramanathan, V., Hansen, J. E., and Sato, M.: Large historical changes of fossil-fuel black carbon aerosols, Geophys. Res. Lett., 30, 1324, doi:10.1029/2002GL016345, 2003.

Park, R. J., Jacob, D. J., Chin, M., and Martin, R. V.: Sources of carbonaceous aerosols over the United States and implications for natural visibility, J. Geophys. Res., 108, D124355, doi:10.1029/2002JD003190, 2003.

Park, R. J., Jacob, D. J., and Logan, J. A.: Fire and biofuel contributions to annual mean aerosol mass concentrations in the United States, Atmos. Environ., 41, 7389-7400, 2007.

Qian, Y., Gustafson Jr., W. I., Leung, L. R., and Ghan, S. J.: Effects of soot-induced snow albedo change on snowpack and hydrological cycle in Western United States based on Weather Research and Forecasting chemistry and regional climate simulations, J. Geophys. Res., 114, D03108, doi:10.1029/2008JD011039, 2009.

Ramana, M. V., Ramanathan, V., Feng, Y., Yoon, S.-C., Kim, S.W., Carmichael, G. R., and Schauer, J. J.: Warming influenced by the ratio of black carbon to sulphate and the black-carbon source, Nat. Geosci., 3, 542-545, 2010.

Ramanathan, V. and Carmichael, G.: Global and regional climate changes due to black carbon, Nat. Geosci., 1, 221-227, 2008.

Randerson, J. T., van der Werf, G. R., Giglio, L., Collatz, G. J., and Kasibhatla, P. S.: Global Fire Emissions Database, Version 2 (GFEDv2) (http://daac.ornl.gov/), Oak Ridge National Laboratory Distributed Active Archive Center, Oak Ridge, Tennessee, USA, 2007.

Seiler, W. and Crutzen, P. J.: Estimates of gross and net ?uxes of carbon between the biosphere and the atmosphere from biomass burning, Climatic Change, 2, 207-247, 1980.

Spracklen, D. V., Logan, J. A., Mickley, L. J., Park, R. J., Yevich, R., Westerling, A. L., and Jaffe, D. A.: Wildfires drive interannual variability of organic carbon aerosol in the Western US in summer, Geophys. Res. Lett., 34, L16816, doi:10.1029/2007GL030037, 2007.

Spracklen, D. V., Mickley, L. J., Logan, J. A., Hudman, R. C., Yevich, R., Flannigan, M. D., and Westerling, A. L.: Impacts of climate change from 2000 to 2050 on fire activity and carbonaceous aerosol concentrations in the Western United States, J. Geophys. Res., 114, D20301, doi:10.1029/2008JD010966, 2009.

Streets, D. G., Gupta, S., Waldhoff, S. T., Wang, M. Q., Bond, T. C., and Bo, Y.: Black carbon emissions in China, Atmos. Environ., 35, 4281-4296, 2001.

Streets, D. G., Bond, T. C., Carmichael, G. R., Fernandes, S. D., Fu, Q., He, D., Klimont, Z., Nelson, S. M., Tsai, N. Y., Wang, M. Q., Woo, J.-H., and Yarber, K. F.: An inventory of gaseous and primary aerosol emissions in Asia in the year 2000, J. Geophys. Res, 108, D218809, doi:10.1029/2002JD003093, 2003.

Tanner, R. L., Parkhursta, W. J., Valentea, M. L., Humesa, K. L., Jones, K., and Gilbertb, J.: Impact of the 1998 Central American fires on $\mathrm{PM}_{2.5}$ mass and composition in the southeastern United States, Atmos. Environ., 35, 6539-6547, 2001.

Turquety, S., Logan, J. A., Jacob, D. J., Hudman, R. C., Leung, F. Y., Heald, C. L., Yantosca, R. M., Wu, S., Emmons, L. K., Edwards, D. P., and Sachse, G. W.: Inventory of boreal fire emissions for North America in 2004: Importance of peat burning and pyroconvective injection, J. Geophys. Res., 112, D12S03, doi:10.1029/2006JD007281, 2007.

VanCuren, R. A. and Cahill, T. A.: Asian aerosols in North America: Frequency and concentration of fine dust, J. Geophys. Res, 107, D244804, doi:10.1029/2002JD002204, 2002.

Van Wagner, C. E.: Development and structure of the Canadian forest fire weather index system, Ottawa, ON, Canadian Forestry Service Technical Report 35, 1987.

van der Werf, G. R., Randerson, J. T., Giglio, L., Collatz, G. J., Kasibhatla, P. S., and Arellano Jr., A. F.: Interannual variability in global biomass burning emissions from 1997 to 2004, Atmos. Chem. Phys., 6, 3423-3441, doi:10.5194/acp-6-3423-2006, 2006.

van der Werf, G. R., Randerson, J. T., Giglio, L., Collatz, G. J., Mu, M., Kasibhatla, P. S., Morton, D. C., DeFries, R. S., Jin, Y., and van Leeuwen, T. T.: Global fire emissions and the contribution of deforestation, savanna, forest, agricultural, and peat fires (19972009), Atmos. Chem. Phys., 10, 11707-11735, doi:10.5194/acp10-11707-2010, 2010.

Walcek, C. J., Brost, R. A., and Chang, J. S.: $\mathrm{SO}_{2}$, sulfate and $\mathrm{HNO}_{3}$ deposition velocities computed using regional landuse and meteorological data, Atmos. Environ., 20, 949-964, 1986.

Warren, S. G. and Wiscombe, W. J.: A model for the spectral albedo of snow II: snow containing atmospheric aerosols, J. Atmos. Sci., 
37, 2734-2745, 1980.

Wells, K. C., Witek, M., Flatau, P., Kreidenweis, S. M., and Westphal, D. L.: An analysis of seasonal surface dust aerosol concentrations in the Western US (2001-2004): Observations and model predictions, Atmos. Environ., 41, 6585-6597, 2007.

Westerling, A. L. and Bryant, B. P.: Climate change and wildfire in California, Clim. Change, 87, 231-249, 2008.

Westerling, A. L., Hidalgo, H. G., Cayan, D. R., and Swetnam, T. W.: Warming and earlier spring increase Western U.S. forest fire activity, Science, 313, 940-943, doi:10.1126/science.1128834, 2006.

Zeng, T. and Wang, Y.: Nationwide summer peaks of OC/EC ratios in the contiguous United States, Atmos. Environ., 45, 578-586, 2011.
Zhang, G. J. and McFarlane, N. A.: Role of convective-scale momentum transport in climate simulation, J. Geophys. Res, 100, 1417-1426, doi:10.1029/94JD02519, 1995.

Zhang, Q., Streets, D. G., Carmichael, G. R., He, K. B., Huo, H., Kannari, A., Klimont, Z., Park, I. S., Reddy, S., Fu, J. S., Chen, D., Duan, L., Lei, Y., Wang, L. T., and Yao, Z. L.: Asian emissions in 2006 for the NASA INTEX-B mission, Atmos. Chem. Phys., 9, 5131-5153, doi:10.5194/acp-9-5131-2009, 2009.

Zwally, H. J., Abdalati, W., Herring, T., Larson, K., Saba, J., and Steffen, K.: Surface melt-induced acceleration of Greenland icesheet flow, Science, 297, 218-222, 2002. 